\title{
The Analysis of Strategy and Tactics by Washington during the American Independent War
}

\author{
Yuyan Zhao \\ College of Elementary Education \\ Linyi University \\ Linyi, China 273400
}

\begin{abstract}
American Independent War is a classic example in world history for a weak force overcoming a superior opponent. The newborn American nation won independence from the British slavery after eight years of staggering battle in North America. General Washington, as the commander in chief of American army, worked on magic and made tremendous contribution for the war with his strategic thinking.
\end{abstract}

Keywords-Washington; American Independent War; strategic thinking

\section{INTRODUCTION}

Between 1607 and 1733, Great Britain established 13 colonies in North America, between the West Atlantic Coast in the east and the Appalachian Mountain in the west. The British colonial government adopted coercion policy in North America in the late 18 century after the development of economy and the emergence of nationalism in the colony, which led to American Independent War. The newborn American nation defeated the strongest colonial power in the world-Great Britain, with laborious 8 years of battles, and founded the United States of America. There are plenty of factors affecting the outcome of the war, of which, General Washington is the determinant.

At the dawn of the war, military forces were made up with local militias, which lack of leadership, organization and discipline. The Colonies established the first standing army, Continental Army, answering to the Continental Congress, on June 14th, 1775, during the Second Continental Conference. The Congress named Washington the Commander in Chief of the Continental Army the next day. With enlisting system and mainly enlisting troops across the colonies, the Continental Army suffered from lack of leadership, organization, management, and supply. Nevertheless, by adopting skirmish and guerrilla tactics, General Washington led such outnumbered, unexperienced, low supplied, and weaponry disordered army, and defeated the better trained British army and won the war eventually, with the support of people and militia from across the colonies.

The unbalanced scale of power determined an endless and formidable war, and founding fathers of the United States such as Washington, thus designed a strategic and tactic of people's war, based on the analysis of the characteristic of the war, the practice of American Army in combat, and the basis of people's war and army.

\section{The Strategic And TACTICAL Thinking OF WASHINGTON}

\section{A. Emphasize on Active Defense and Limit on Passive Defense}

Washington believes defense should be active instead of passive, "We should hit the enemy with head on, as soon as there is the smallest possibility of advantage for attack." (1) Washington eliminated enemy forces while preserving effective strength by estimation of the strategic situation and calculation of the balance of power. He insisted on the strategy of defense and avoided full-scale battles in any condition, disregard the onerous situation, to avoid any unnecessary risks of his troops. (2)

It was a dire situation when Long Island in New York State was surrounded by an overwhelming number of British army in 1776. The British Army maneuvered frequently and intended to eliminate the entire Colonial army. Nevertheless, Washington realized that the British army seek to eliminate the entire, or part of the American army, by forcing it into a decisive engagement. He insisted, "We should insist on defensive battle, and avoid open battles in any circumstances unless it cannot be avoided." (3) Thus, in the situation of outnumbered, out-gunned, and impossible to defense, he, in a military meeting, insisted that the American should avoid a decisive battle, abandon Long Island and withdraw into New York City.

Since the August of 1776, the Continental Army retreated from Long Island to New York City and then all the way to the west bank of Delaware River. While the British Army was jauntily chasing the American troops, neglectful of precautions, Washington surprised the British troops by a swift attack on Trenton on December 25th, with 2,400 men and 20 cannons, divided into 3 divisions. The battle was an astonishing victory

\footnotetext{
(1) Russell Wrigley, the History of the U.S. Military Strategy and Policy [M], Beijing People's Liberation Army Publishing House, 1986, P. 24, 24, $24,27$.

(2) Calvin Linton, the Bicentennial Almanac [M], Shanghai Translation Publishing House, 1984, P. 298.

(3) Shuzhi Peng, Biography for World's most Famous Generals [M], Xi'an Three Qin Publishing House, P. 166
} 
with minimal casualties on the American side while eliminating almost a thousand British troops. However, the British gathered a huge army, marching to Trenton, led by Sir Cornwallis, who claimed that he would capture the fox, Washington by the next day. The situation was on the hazard. Washington planned tactics carefully. He divided his troops into three groups: One group dug trenches near the bridge and the enemy line, while making noise until dawn; one group patrols in the camp to keep camp fire on and maintain the camp; Washington himself led most of his troops out of the camp undetected and maneuvered to sneak attack the British troops in Princeton. Washington was a smart man, taking chances when the opportunity presents. Washington avoided enemy's main force and strike at is weak point, and killed about 100 British troops and captured almost 300, while losing only about 25 men during the short but glorious skirmish. This brought hope of victory to the colonial militias. Washington earned his name as the "American Fabius" from politicians and generals in Europe, because of his excellent military tactics. Prussian King Friedrich, war in Europe called those two battles the most prestigious victories in military history.

\section{B. Adopt Guerrilla Tactics and Avoid Tough Battles}

General Washington's guerrilla tactics had two contents: one, focus on annihilating enemy effectives, disregard loss of settlement; the other one, use mobile guerilla tactics constantly, use the benefit of fighting in interior line and by militia troops, use fast mobility, set traps, and arrange sub-coordinated attacks.

During the American Independent War, Washington strategically cut off British supply, and constantly harried his opponent. He sent militias to nearby village to eliminate scattered enemy troops while send out patrols and scouts to monitor the enemy. He sent troops to kill British foraging teams to cut off British supply line, so that the British army could only garrison in cities or towns, and be separated from the countryside; thus British army turned into an isolated force.

The British launched full assault on Philadelphia, the capital city of United States at the time, on September 1777, with superior power, which led to the abandonment of Philadelphia by the American troops after a fierce defensive battle. The loss of the temporal capital left a shadow on the American people, but Washington was hardheaded about the situation because he knew the victory of a war is not limited to the gain or loss of each cities. Thus, he wrote to the governor to ask him and the people remain calm, "I hope the damage of this incident is not as serious as what people fear for, and that with endless efforts and good timing, we will gain opportunity to regain the loss territory and boost out cause."(4) Washington started planning on settling the score the moment of defeat, and the best way is to fight for victory. He boosted the moral and prowess of Continental Army once again in half a month's time, by sneak attack on Germantown, which made the British Army hold the Continental Army in high esteem.

\footnotetext{
(4) Washington Owen, the Era of Washington [M], Beijing Oriental Publishing House, 2005, P. 308, 218, 151, 407, 414.
}

Washington appointed eight brigadier generals during the American Independent War, of which, General Nathanael Greene was the most trusted, acting as one of the most passionate, loyal and efficient lieutenant of Washington. He, adapted from Washington, combined the standing army with guerrilla army and defeated his enemy with depletion.

Washington wrote to Greene during the battle of Fort Washington in November 1776, "What advantage can it bring to hold a fort if we cannot stop the enemy warships from advancing upstream and thus lost all surrounding territory to the fort? I think it's unwise to let the troops and strategic materials in Washington Mountain to fall into enemy's hand, and since you are in the battle field, I urge you to order troops to retreat from Washington Mountain based on your judgment, and recall Colonel Margo's order to stand the ground." 5

The war in Northern United States fell into a statement after the battle of Saratoga, and Washington appointed Greene Commander in Chief for the Southern Theatre, replacing Gates who lost the battle of Camden. Greene regrouped the scattered army in the south, and implied guerrilla tactics, by diving his army into three divisions: 600 troops heading west, led by Morgan; 280 cavalries and infantries, led by "Harry the Ranger", heading east to join guerrilla troops in Marion; Greene led the main body of the army to boost its discipline. Three divisions of army cooperated and coordinated with each other, gathering and maneuvering to eliminate the opponent in movement, which tactic helped regaining most of the territory in south and forced the British troops to retreat to several coastal cities.

Washington combined attack and defense tactics during the American Independence War: He imply persisting interior line defensive warfare in strategic, and fast mobile exterior line offensive warfare tactics. With constant sift of defense and offense, he gradually impaired the enemy, turned the balance of war, and switched to strategic offense from defense with excellent timing.

\section{Focus on Fast Joint Attack Instead of Division of Troops in Defense}

Washington emphasis during the war, "Once the battle commences, we should regroup the troops in coordinated areas to form a strike force in ground zero, to support the defense of enemy aggression... Dividing the troops unwisely, an army with superior power could be defeated by one with inferior power." "We shall not divide our troops and lose the advantage in number...Our army should be united as one..., He pointed out that concentration of force is to, "hit the enemy with head on once a slightest possibility of advantage present itself..." (7) Washington emphasize on a sudden, swift, and surprise attack in offense, which can be indicated in the battle of Trenton and Princeton. Washington had an impatient characteristic, but he follow the principle that, "Prudent orders

\footnotetext{
(5) Washington Owen, the Era of Washington [M], Beijing Oriental Publishing House, 2005, P. 308, 218, 151, 407, 414.

${ }^{6}$ Russell Wrigley, the History of the U.S. Military Strategy and Policy [M], Beijing People's Liberation Army Publishing House, 1986, P. 24, 24, 24,27

${ }^{7}$ Russell Wrigley, the History of the U.S. Military Strategy and Policy [M], Beijing People's Liberation Army Publishing House, 1986, P. 24, 24, $24,27$.
} 
should be examined carefully and thoroughly before being adopted..., ,8

First arrived at the Boston frontline as Commander in Chief for the Continental Army, Washington realized that the American defense line was too scattered and could be easily cut in half. As a result, he decided to build a series of forts on the defense line for a better protection during a military meeting. July 1775, when Washington planned to concentrate all forces on the siege of Boston, the council of Massachusetts and governor of Connecticut asked him to divide his force to protect the coastal cities, the event, which was a crucial moment for the fate of war. Washington spoke bluntly about the strategy of the war, "...will greatly weaken our force, and make it vulnerable, which will also leave coastal regions unprotected...Our strategy must focus on the big picture, without neglecting any regions...",

Before retaking Philadelphia in August 1781, Washington adopted a tactic of diversion, after thinking prudently and decided to lead the army himself. He carefully planned the assault by making a feign attack on New York, even confusing the American army, while led the main south force himself, coordinating a joint attack to completely surround the British troops. Washington finished the pre-battle preparation within a week, "Now we had passed all the enemy outposts in the frontline, and force marching to Philadelphia with light supply...General Washington had shown great leadership in command and forced his opponent think of the disgraceful situation they are in, namely, forcing Sir Cornwallis to be in a mortal danger in any condition." "(10) At that point, Washington stated, "Right now each day of delay is a delay for years. Thus as long as we can ensure our safety, we should move the battlefield into the enemy territory...Each day we give our enemy for further preparation could cost more live on our side in battle." 11 Due to the thorough plans of tactics by Washington and after sustained cannon fire, the British troops were scattered, routed, and constantly retreating. Sir Cornwallis asked for a cessation of fire and surrendered to General Washington on October 17th.

\section{CONCLUSION}

During the American Independent War, Washington turned a lowly equipped, low-disciplined, and disorganized militia of mobs into a battle-hardened, brave standing army, with great efforts. He brought victory to American Independence with grittiness, resolution, and strategy.

After induction of military practice of the colonial army and examples from the history of military, founding fathers of the United States made a systematic military strategy for

\footnotetext{
${ }^{8}$ Russell Wrigley, the History of the U.S. Military Strategy and Policy [M], Beijing People's Liberation Army Publishing House, 1986, P. 24, 24, $24,27$.

${ }^{(9)}$ Washington Owen, the Era of Washington [M], Beijing Oriental Publishing

House, 2005, P. 308, 218, 151, 407, 414.

(1) Washington Owen, the Era of Washington [M], Beijing Oriental Publishing

House, 2005, P. 308, 218, 151, 407, 414.

${ }^{11}$ Washington Owen, the Era of Washington [M], Beijing Oriental

Publishing House, 2005, P. 308, 218, 151, 407, 414.
}

American Independence War, based on the principle of people's army and people's war.

\section{REFERENCES}

[1] Liu Zuochang.1954. "A History for American Independence War" [M].Shanghai East China People's Publishing House.

[2] T.O.Lloyd.1984. "The British Empire (1558-1983)” [M]. Oxford.

[3] Russell Wrigley."A History of the United States Army" [M]. Beijing People's Liberation Army Publishing House.

[4] Yu Zhisen.1992. "The Story of America" [M].East China Normal University Publishing House.

[5] Guan Xunxia.2004. "Thoughts on Governing Troops and Military Talents of Washington during the American Independent War'[J]. South China Normal University Press.

[6] "The Encyclopedia American History VI" [M]. New York, 1977.

[7] Clausewitz.1964."On War (Vol. 2)” [M]. People's Liberation Army Publishing House. 